\title{
Corrosion and scale studies of copper used in Moroccan industrial cooling water systems
}

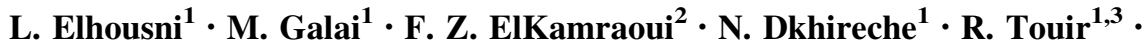 \\ M. Ebn Touhami ${ }^{1}$
}

Received: 23 September 2016/Accepted: 12 June 2017/Published online: 21 June 2017

(c) Springer International Publishing AG 2017

\begin{abstract}
The corrosion and scale behavior of copper in industrial cooling water system were investigated via electrochemical measurements, ionic chromatography, SEM/EDAX, and X-ray diffraction analyses. It was found that the studied water has a corrosion and scale character. The EDAX and XRD analyses indicated that the major corrosion and scale products were the $\mathrm{CuO}_{2}$ and $\mathrm{CaCO}_{3}$, respectively. In addition, the middle Mueller-Hinton test was also employed to evaluate the development of microorganisms for copper in make-up water solution. It is noted that bacterial colonies appeared after immersion of samples in make-up water, indicating that this water develops bacterial colonization. Finally, the influence of some operating parameters on the corrosion and scale rate was studied. It was shown that the scale rate increases with $\mathrm{pH}$, temperature, and the addition of chloride and sulfide ions. It was also found that the corrosion rate increases with temperature and chloride ions and decreases with $\mathrm{pH}$ and immersion time.
\end{abstract}

Keywords Corrosion - Scaling and microorganism . Copper - Industrial cooling water - SEM/EDAX $\cdot$ XRD . Ionic chromatography

R. Touir

touir8@yahoo.fr; touir8@gmail.com

1 Laboratoire d'Ingénierie des Matériaux et d'Environnement : Modélisation et Application, Faculté des Sciences, Université Ibn Tofail, BP 133, Kénitra 14 000, Morocco

2 Laboratoire Physico-chimique des Matériaux et Nanomatériaux, Faculté des Sciences de Rabat Agdal, Université Mohamed V, Rabat, Morocco

3 Centre Régional des Métiers de l'Education et de la Formation (CRMEF), Avenue Allal Al Fassi, Madinat Al Irfane, BP 6210, Rabat, Morocco

\section{Introduction}

Owing to their excellent proprieties, copper and its alloys are used in several important industries (ELbakri et al. 2008). However, they are susceptible to different forms of corrosion such as pitting corrosion. So, the water used as a thermal fluid in cooling circuits usually leads to three problems, namely, corrosion, scaling, and microorganism development. These phenomena are the source of a loss of the metallic material, a decrease of the thermal efficiency of the circuit, and the proliferation of microorganisms in the water, respectively, (Touir et al. 2010; Srisuwan et al. 2008). Indeed, iron is the principal redox-active metal in the metabolic processes of essentially all living organisms. It is either involved in catalytic quantities as a component of a large number of proteins, or at much higher substrate amounts as the external electron donor or acceptor for specially adapted environmental microorganisms called 'iron bacteria' (ferrotrophic bacteria, aerobic or anaerobic) or 'iron bacteria' respectively (Enning et al. 2012). In most biological functions, iron has the state of oxidation + II (ferrous) or + III (ferric). From a physiological point of view, it appears astounding that also the native, metallic element $\left(\mathrm{Fe}^{0}\right)$ can be involved in a biological process; this is anaerobic microbial corrosion. In technology, the process is often referred to as microbially influenced corrosion (MIC) (Enning et al. 2012; Hamilton 1985; Lee et al. 1995).

However, the bio-corrosion is the effect of microorganisms on the kinetics of the corrosion processes of materials; whereas the bio-film is the adherence of these microorganisms on the corroded wall (Chantereau 1980). So, the microorganisms are bacteria belonging to the family of Gram-aerobic or facultative anaerobic Enterobacteriaceae, namely Escherichia coli, Klebsiella 
pneumoniae pseudomonadaceae, Pseudomonas aeruginosa and Achromobacteriaceae (Bacillus subtilis). Therefore, the bio-film has evolved over time depending on the bacteria that make it up. So, the bio-film is composed not only of water and bacteria but also of organic substances secreted by microorganisms or lysis of bacteria. These are extracellular exopolymers.

Usually, the use of acid in order to remove scale caused a risk for materials (corrosion). However, the scale deposition can, in some cases, protect the pipes against corrosion. Indeed, the presence of a certain quantity of $\mathrm{CO}_{2}$ is necessary for it is neither aggressive nor calcifying. If this amount was large, the water was aggressive and was therefore not calcifying. For this, many calculation methods have been proposed to determine the scaling tendency.

On the other hand, the corrosion phenomenon is a serious global problem for metallic materials (Qiang et al. 2016; Herrmann et al. 2014). As a very classic example, copper is the most important metal used in industries, which can be corroded seriously in the marine environment due to the existence of aggressive chloride ions (Chen et al. 2012; Sherif and Park 2005).

However, Kartsonakis et al. studied the copper corrosion inhibition in industrial cooling water systems by electrochemical techniques and microscopic observations. They found, under specific conditions (e.g., high $\mathrm{pH}$ ), that the studied water has a corrosive character (Kartsonakis et al. 2015)

On the other side, to attenuate or eliminate these problems, waters used in cooling circuits are treated with inhibitive formulations. So, Touir et al. studied the influence of sodium gluconate (SG) associated with cetyltrimethylammonium bromide (CTAB) on low-carbon steel corrosion in simulated cooling water using electrochemical measurements. They showed that the obtained formulation has good inhibition for low-carbon steel corrosion in the studied medium (Touir et al. 2014).

In addition, Soror studied the effect of polyacrylamide on carbon steel and copper corrosion in simulated cooling water using scale, Tafel, linear polarization measurements, and optical microscopy. He obtained that the this polymer decreases scale build-up growth and acts as an anodic-type corrosion inhibitor of carbon steel and mixed-type of copper (Soror 2009).

Therefore, the objective of the present work is to study the corrosion and scale of copper in a cooling water system using electrochemical measurements, ionic chromatography, SEM/EDAX, and XRD analyses. The middle Mueller-Hinton test was also employed to assess the microorganisms development. Indeed, the effect of some operating parameters on the corrosion and scale process of copper was investigated.

\section{Experimental procedure}

\section{Presentation of the water study conditions}

In this study, we have taken as a corrosive medium a solution of water used in cooling circuits of the foundry of the MAC/Z Company of Skhirat/Morocco. In order to ensure a satisfactory conservation of the physicochemical characteristics of the used water, samples of representative homogeneous water were taken in clogged, protected, isothermal containers in the dark at temperature of $277 \pm 2 \mathrm{~K}$. In addition, in order to avoid any incompatibility between reality and experimental work, we worked in the laboratory with real water from the company (almost $45 \mathrm{~min}$ from the laboratory).

\section{Physicochemical analyzes}

Conductivity, $p H, T D S$, salinity, and temperature

For measuring conductivity, $\mathrm{pH}$, TDS, salinity, and temperature, a conductivity meter AH4400 was used.

\section{COD measurement}

Chemical oxygen demand (COD) represents the oxygen consumption by strong chemical oxidants to oxidize organic and mineral water. It allows assessing the pollution load of wastewater. Assessing the oxygen quantity $\left(\mathrm{mg} \mathrm{l}^{-1}\right)$, used by the oxidation reactions, for the measurement of the reactants residue after $2 \mathrm{~h}$. Oxidation is performed hot, in an acid medium, in the presence of an excess of oxidant. In a tube COD reagents, $2 \mathrm{ml}$ of distilled water, boiling at $532 \pm 2 \mathrm{~K}$ for $2 \mathrm{~h}$, and after cooling we read the $\mathrm{COD}$ value at the colorimeter.

\section{Measurement of BOD5}

The biochemical oxygen demand over 5 days (BOD5) represents the oxygen amount required by microorganisms to oxidize (degrade) the total organic substance of water maintained at $293 \pm 2 \mathrm{~K}$ and in the dark for 5 days. To measure this parameter, it firstly measured the oxygen concentration in a sample of water and repeated this measurement 5 days later. So, BOD5 represents the difference between the two concentrations.

\section{Ion chromatography}

To determine the inorganic anions in water, Thermo Scientific Dionex DX-120 and Thermo Scientific Dionex DX500 Ion Chromatography Systems were used. So, the 
Dionex DX-120 is a dedicated ion chromatography; the Dionex DX-500 is a modular system. For several analyses, $1000 \mathrm{mg}^{-1}$ standard solutions are available from Thermo Scientific and other commercial sources. When these solutions are not available, $1000 \mathrm{mg}^{-1}$ standards can be prepared by dissolving the appropriate amounts of the corresponding mass in $1000 \mathrm{ml}$ of deionized water.

\section{Microbiological study}

The medium used is a solid medium where the culture medium of TSA (Tryptic Soy Agar, Difco, Detroit, MI, USA). The inoculation is at $310 \pm 2 \mathrm{~K}$ for $18-24 \mathrm{~h}$ in the dark.

\section{Electrochemical study}

A conventional three-electrode system assembly with copper working electrode, $\mathrm{Ag} / \mathrm{AgCl}$ electrode, and platinum electrode was used for electrochemical measurements. The chemical composition of copper is summarized in Table 1. The copper coupons were embedded in epoxy resin leaving $4.52 \mathrm{~cm}^{2}$ cross-sectional areas exposed to the corrosive medium for electrochemical experiments. Prior to each experiment, the copper substrates were abraded consecutively with a series of emery papers (from 100 to 1200 grit), and then they were cleaned with acetone, washed with distilled water, and dried in hot air.

Prior to each electrochemical measurement, the working electrode was immersed in aggressive solution for $1 \mathrm{~h}$ at open circuit potential $\left(E_{\mathrm{OCP}}\right)$ to reach an almost steady state. Subsequently, EIS measurements were performed at the $E_{\mathrm{OCP}}$ in the frequency range from $100 \mathrm{kHz}$ to $0.01 \mathrm{~Hz}$ using sinusoidal AC perturbation with an amplitude of $5 \mathrm{mV}$. The EIS data were analyzed and fitted by EC-Lab software. At last, polarization experiments were performed by changing the electrode potential automatically from negative values to positive values versus $E_{\mathrm{OCP}}$ using a potentiostat/galvanostat type PGZ 100, with a scan rate of $1 \mathrm{mV} \mathrm{s}^{-1}$. All measured potential values were referred to the $\mathrm{Ag} / \mathrm{AgCl}$ electrode. The same experiment was carried out three times to guarantee a favorable reproducibility. To evaluate corrosion kinetic parameters, a fitting by SternGeary equation was used (Ben Amor 1999). The test solution was thermostatically controlled at $298 \pm 2 \mathrm{~K}$ in air atmosphere.

\section{Scanning electron microscope and X-ray diffraction analyses}

To investigate the morphology and composition of the copper surfaces, the specimens were examined using a scanning electron microscope (SEM; JOEL JSM-5500) equipped with EDAX analyzer. Indeed, the phase present in the specimens was determined over the $2 \theta$ scale range from $20^{\circ}$ to $90^{\circ}$ using a Philips X-ray diffractometer X'Pert MPD.

\section{Results and discussion}

\section{Characterization of make-up water}

Moroccan industry of aluminum, copper, and zinc used water of the foundry MAC/Z Company of Skhirat/Morocco, where its chemical composition is given in Table 2. It is shown that this water contains the elements responsible for corrosion such as $\mathrm{Cl}^{-}$ions and dissolved oxygen and the elements responsible to scale formation such as $\mathrm{Ca}^{2+}, \mathrm{Mg}^{2+}, \mathrm{HCO}_{3}{ }^{-}$ions. It is noted also the presence of sulfates responsible to corrosion and the development of microorganisms such as sulfate-reducing bacteria. So, Enning et al. indicated that the iron corrosion in anoxic environments (e.g., inside pipelines) is largely influenced by microorganisms, in particular sulfate-reducing bacteria (SRB). The process is characterized by the formation of black crusts and metal pitting. The mechanism is usually explained by the corrosive character of the formed $\mathrm{H}_{2} \mathrm{~S}$ and scavenges of 'cathodic' $\mathrm{H}_{2}$ from the chemical reaction of iron with $\mathrm{H}_{2} \mathrm{O}$ (Enning et al. 2012). For this, we have characterized this water for the development of the above problems.
Table 1 Chemical composition of copper

\begin{tabular}{lllllllll}
\hline Elements & $\mathrm{Zn}$ & $\mathrm{Pb}$ & $\mathrm{P}$ & $\mathrm{Mn}$ & $\mathrm{Fe}$ & $\mathrm{Ni}$ & $\mathrm{Si}$ & $\mathrm{Mg}$ \\
\hline $\mathrm{Wt} \%$ & 0.0031 & 0.0022 & 0.0008 & $<0.0004$ & 0.0022 & 0.0054 & $<0.0005$ & 0.0002 \\
\hline Elements & $\mathrm{Cr}$ & $\mathrm{Te}$ & $\mathrm{As}$ & $\mathrm{Sb}$ & $\mathrm{Cd}$ & $\mathrm{Bi}$ & $\mathrm{Ag}$ & $\mathrm{Co}$ \\
\hline $\mathrm{Wt} \%$ & $<0.0003$ & 0.0073 & $<0.0002$ & $<0.0005$ & $<0.0002$ & $<0.0005$ & 0.0014 & $<0.0010$ \\
\hline Elements & $\mathrm{Al}$ & $\mathrm{S}$ & $\mathrm{Zr}$ & $\mathrm{Au}$ & $\mathrm{B}$ & $\mathrm{Ti}$ & $\mathrm{Se}$ & $\mathrm{Cu}$ \\
\hline Wt\% & $<0.0005$ & $<0.0002$ & $<0.0003$ & $<0.0005$ & $<0.0004$ & $<0.0002$ & $<0.0002$ & 99.976 \\
\hline
\end{tabular}


Table 2 Physicochemical characterization of make-up water used in Moroccan industry

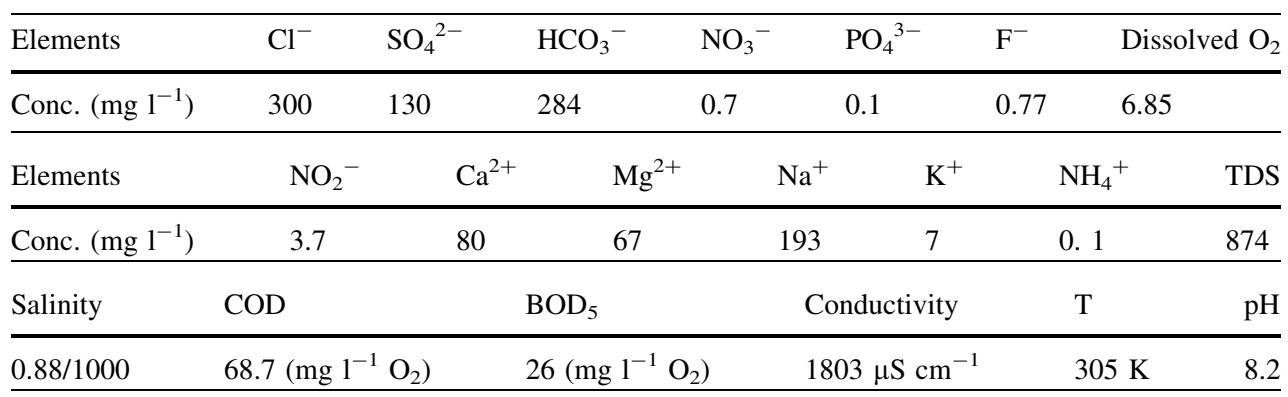

\section{Evaluation of corrosion, scale, and biofiling of make-up water}

\section{Evaluation of corrosion and scale of make-up water}

\section{Predicting of scale formation}

The scale and corrosion phenomenon are qualitatively predicted using various indices, namely the Langelier Saturation Index (LSI), the Rysnar Stability Index (RSI), and the Puckorius Scaling Index (PSI) (Langelier 1936; Ryznar 1944; Puchorius and Brooke 1988; Harris and Marshall 1981), which depend upon water parameters. So, the LSI is an indicator of the scale potential of cooling water. Thus a negative LSI indicates no potential to scale; the water will dissolve $\mathrm{CaCO}_{3}$, while a positive value indicates $\mathrm{CaCO}_{3}$ precipitation. In addition, an RSI $>6$ indicates corrosion while RSI $<6$ indicates scale formation. In addition, the PSI has the same indication as RSI. In fact, we have calculated the LSI and RSI at different temperature ranges from 295 to $335 \mathrm{~K}$. This choice of temperature range based on those water temperatures can reach $313 \mathrm{~K}$ in a Moroccan cooling water system. Table 3 presents the obtained results at different temperature values. It was noted that all the Langelier Saturation Index (LSI) values were positive, which justified the formation of calcium carbonate. In addition, the Ryznar Stability index (RSI) value predicts that the sample at $295 \mathrm{~K}$ was under threat of corrosion and light scale. At the temperature range from 305 to $335 \mathrm{~K}$, the RSI values changed in the range from 5 to 7 , which means and predicts that the water is scaling and slightly corrosive.

However, these findings can be explained by the large amount of dissolved oxygen diffusing, which increases the amount of hydroxyl $\mathrm{HO}^{-}$formed by two electrochemical reactions:

$\mathrm{O}_{2}+2 \mathrm{H}_{2} \mathrm{O}+2 e^{-} \rightarrow \mathrm{H}_{2} \mathrm{O}_{2}+2 \mathrm{OH}^{-}$

$\mathrm{H}_{2} \mathrm{O}_{2}+2 e^{-} \rightarrow 2 \mathrm{OH}^{-}$
Table 3 Hardness of the used make-up water at different temperature $[10,11]$

\begin{tabular}{lllll}
\hline Temperature $(\mathrm{K})$ & $\mathrm{pH}_{\mathrm{s}}$ & LSI & $\mathrm{RSI}$ & Scale conditions \\
\hline 295 & 7.7 & 0.48 & 7.2 & Slightly scaling and corrosive \\
305 & 7.5 & 0.69 & 6.8 & Scaling and corrosive \\
315 & 7.3 & 0.88 & 6.4 & Scaling and slightly corrosive \\
325 & 7.1 & 1.1 & 6.1 & Scaling and slightly corrosive \\
335 & 7 & 1.2 & 5.7 & Slightly scaling and corrosive \\
\hline
\end{tabular}

However, the $\mathrm{HO}^{-}$ions formed at the electrode surface induce an increase in local $\mathrm{pH}$, causing precipitation of calcium carbonate (Ketrane et al. 2009). In addition, the chemical reaction causing the precipitation of calcium carbonate was widely promoted by temperature by the carbon dioxide release and thus accelerates the scale formation. There was little or no scale on cold water pipes. In contrast, at hot water systems the scale was formed. In fact, we noted an increase in the hardness of water with temperature. In order to confirm these results, we have conducted an experimental study using ion chromatography and spectroscopic analyzes.

\section{Dosage of $\mathrm{Ca}^{2+}$ ions by ionic chromatography}

To confirm previous theoretical results, we have evaluated the free $\mathrm{Ca}^{2+}$ concentrations in the solution before and after immersion of the copper substrate for $24 \mathrm{~h}$ at $323 \mathrm{~K}$ by ion chromatography. The obtained results are shown in Table 4, which indicates that the $\mathrm{Ca}^{2+}$ ion concentration in the solution decreases remarkably from 80 to $55 \mathrm{ppm}$, indicating the formation of the scale at the electrode surface. In addition, the observation of the electrode surface with the eye (Table 4) indicated that the surface is covered by a distinct purple corrosion and scale products layer. To ensure the scale and corrosion character of the studied water, qualitative and quantitative analyses with SEM/ 
Table 4 Free ions $\mathrm{Ca}^{2+}$ concentrations before and after immersion of copper substrate in make-up water for $24 \mathrm{~h}$ at $323 \mathrm{~K}$

\begin{tabular}{llll}
\hline & {$\left[\mathrm{Ca}^{2+}\right](\mathrm{ppm})$} & Surface state \\
\hline Water before test & 80 & \\
Water after $24 \mathrm{~h}$ of immersion at $323 \mathrm{~K}$ & 55 & \\
\hline
\end{tabular}

EDAX analysis under the same conditions were carried out.

\section{SEM and X-ray diffraction analyses}

The evolution of surface states of copper using SEM analysis was carried out after $24 \mathrm{~h}$ of immersion at $323 \mathrm{~K}$. Figure 1a shows the electrode surface of copper before any attack. It is shown that the surface was clean and homogeneous. However, Fig. 1b shows the state surface after $24 \mathrm{~h}$ of immersion at $323 \mathrm{~K}$. It is noted that the apparition of a thick layer of products reflected the development of a thick film on the electrode surface. In fact, this layer was heterogeneous and exhibits at least two colors, one black, which may be due to the presence of corrosion products, and the other white, which may be due to scale products. In fact, EDAX analysis (Fig. 2a) showed that the formed layer was composed of several elements such as magnesium, calcium, copper, carbon, and oxygen with a strong predominance calcium (13.05 wt $\%$ ), carbon (44.67 wt\%), and oxygen (28.45 wt\%). This result confirmed that the formed layer was composed of corrosion and scale products. It is also remarked the appearance of a sulfur peak $(0.64 \mathrm{wt} \%)$ which can be indicated the development of sulfate-reducing bacteria, such as found by Enning et al. when they studied the marine sulfatereducing bacteria on iron corrosion under electro-conductive biogenic mineral crust (Enning et al. 2012). In addition, the development of $\mathrm{Cu}_{2} \mathrm{~S}$ is the primary surface process on copper specimens where its corrosion protection properties improve by bio-film growth, which becomes less sensitive to $\mathrm{Cl}^{-}$attack (Huttunen-Saarivirta et al. 2016).
Figure $2 \mathrm{~b}$ shows the XRD analysis of the copper surface after $24 \mathrm{~h}$ of immersion in make-up water at $323 \mathrm{~K}$. It is shown that the formed layer of corrosion products was composed of copper oxides such as cuprites $\left(\mathrm{Cu}_{2} \mathrm{O}\right)$. The same results were found by other authors when they studied the copper corrosion under biotic and abiotic conditions in anoxic ground water (Huttunen-Saarivirta et al. 2016). In fact, their experiments were carried out in acid-washed ethanol (70\%) sterilized vessels of the volume of 121 that were essentially gas tight. Prior to the experiments, the ethanol-sterilized specimens and the electrodes were placed aseptically in the vessels, which were first flushed with $\mathrm{N}_{2}$ to remove oxygen and then filled with anoxic artificial groundwater. This study included two vessels: one was made biotic by adding $50 \mathrm{ml}$ of enrichment culture of sulfate-reducing bacteria (SRB) and the other abiotic, which was tested as such (Huttunen-Saarivirta et al. 2016). Indeed, the accumulation of $\mathrm{Cu}_{2} \mathrm{O}$ on the copper surfaces either alone (Eriksen et al. 1989; Bojinov et al. 2010; Bech-Nielsen et al. 2002; Trachli et al. 2002; Kosec et al. 2015; Sherif and Park 2005; Merkel and Pehkonen 2006) or with some $\mathrm{CuCl}$ (Merkel and Pehkonen 2006; Kear et al. 2004) was frequently reported with another suggestion (Kosec et al. 2015; Sherif and Park 2005; Merkel and Pehkonen 2006) that the formed $\mathrm{CuCl}$ may react more late with water to introduce $\mathrm{Cu}_{2} \mathrm{O}$.

However, the appearance of calcium carbonate peak with great intensity is also noted, indicating the formation of a thick layer of scale confirming the previously obtained results. 
Fig. 1 SEM micrograph surface of copper (a) before immersion in make-up water solution (b and b') after $24 \mathrm{~h}$ of immersion in make-up water solution at $323 \mathrm{~K}$

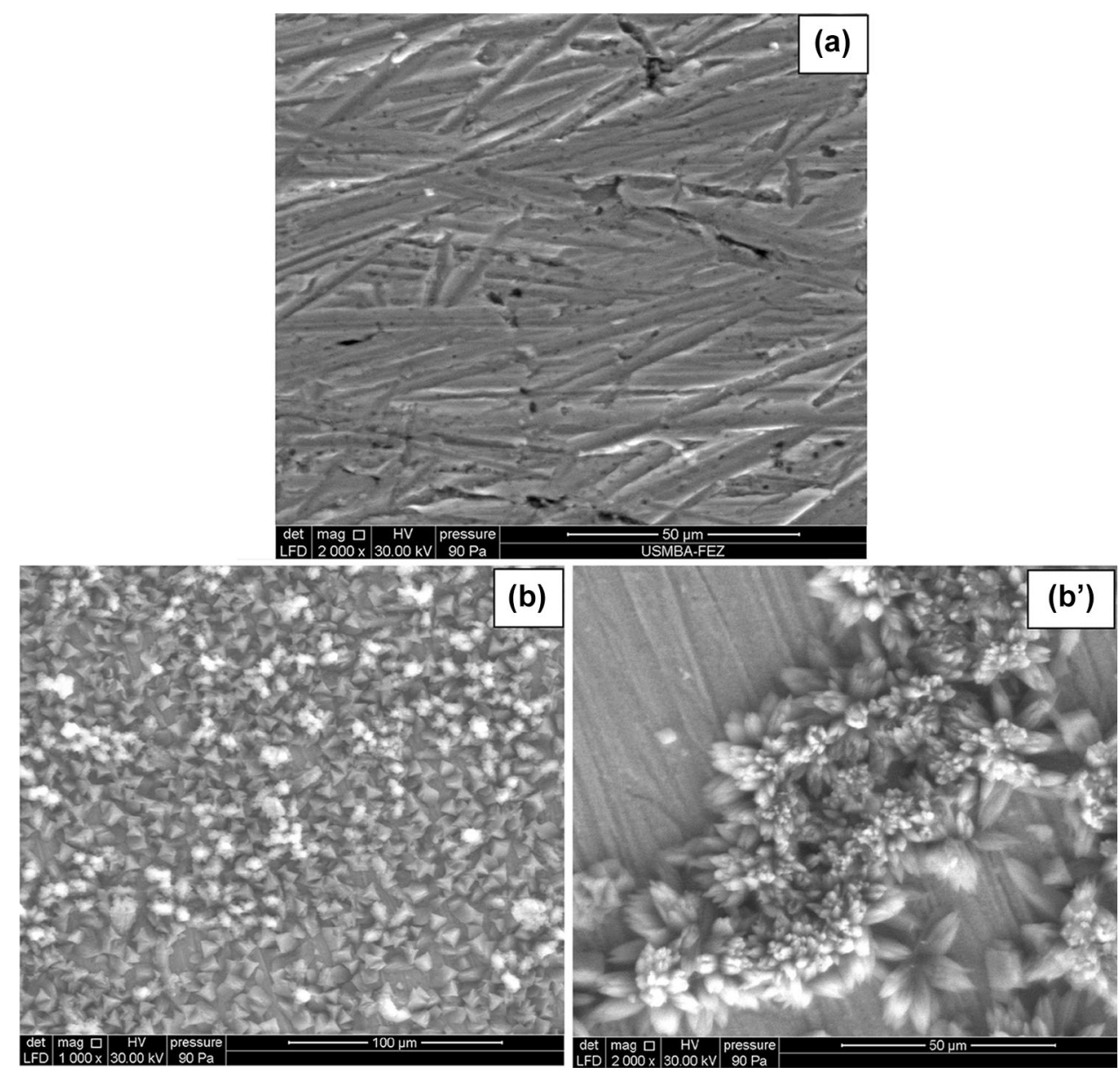

\section{Bacterial study of the make-up water}

In this study, we have determined the character of make-up water for the development of microorganisms according to the middle agar diffusion method on the middle MuellerHinton. The obtained results are shown in Fig. 3. The appearance of bacterial colonies after immersion of samples in make-up water is noted, indicating that this water develops bacterial colonization. The same results were obtained when they studied the antibacterial properties of the 316L-Cu SS before and after passivation (Zhao et al. 2016)

In addition, after identifying the problems encountered in the cooling water system of copper (scale, corrosion, and development of microorganisms), we investigated the effect of some operating parameters on the evolution of these problems.

\section{Electrochemical corrosion evaluation}

Figure $4 \mathrm{a}$ represents the potentiodynamic polarization curve of copper electrode in make-up water at $305 \mathrm{~K}$. It is noted that the anodic current increases exponentially with applied potential, indicating kinetic charge transfer. Then, the corrosion potential $\left(E_{\text {corr }}\right)$ and corrosion current density $\left(i_{\text {corr }}\right)$ which were obtained by using Stern-Geary equation $\left(i_{\text {corr }}=\right.$ is $8.44 \mu \mathrm{A} \mathrm{cm}^{-2}$ ) indicated that used water has a corrosive character.

Therefore, the anodic reaction involved in this case is the copper oxidation:

$\mathrm{Cu} \rightarrow \mathrm{Cu}^{2+}+2 e^{-}$

In addition, a current inflection at potential of $0.2 \mathrm{~V} / \mathrm{Ag} /$ $\mathrm{AgCl}$ may be attributed to the formation of $\mathrm{CuO}_{2}$ and/or $\mathrm{CuO}$ layers, as shown by the above XRD spectra.

At the cathodic range, the main reaction was the dissolved oxygen reduction, according to the following reaction:

$\mathrm{O}_{2}+2 \mathrm{H}_{2} \mathrm{O}+4 e^{-} \leftrightarrow 4 \mathrm{HO}^{-}$

Beyond $-1 \mathrm{~V} / \mathrm{Ag} / \mathrm{AgCl}$, the reduction of the water takes place to produce hydrogen gas.

However, the copper can be migrated deep under particular drainage conditions or in a highly acidic environment and can therefore contaminate groundwater. In order to minimize the copper amount, a new biodegradable 

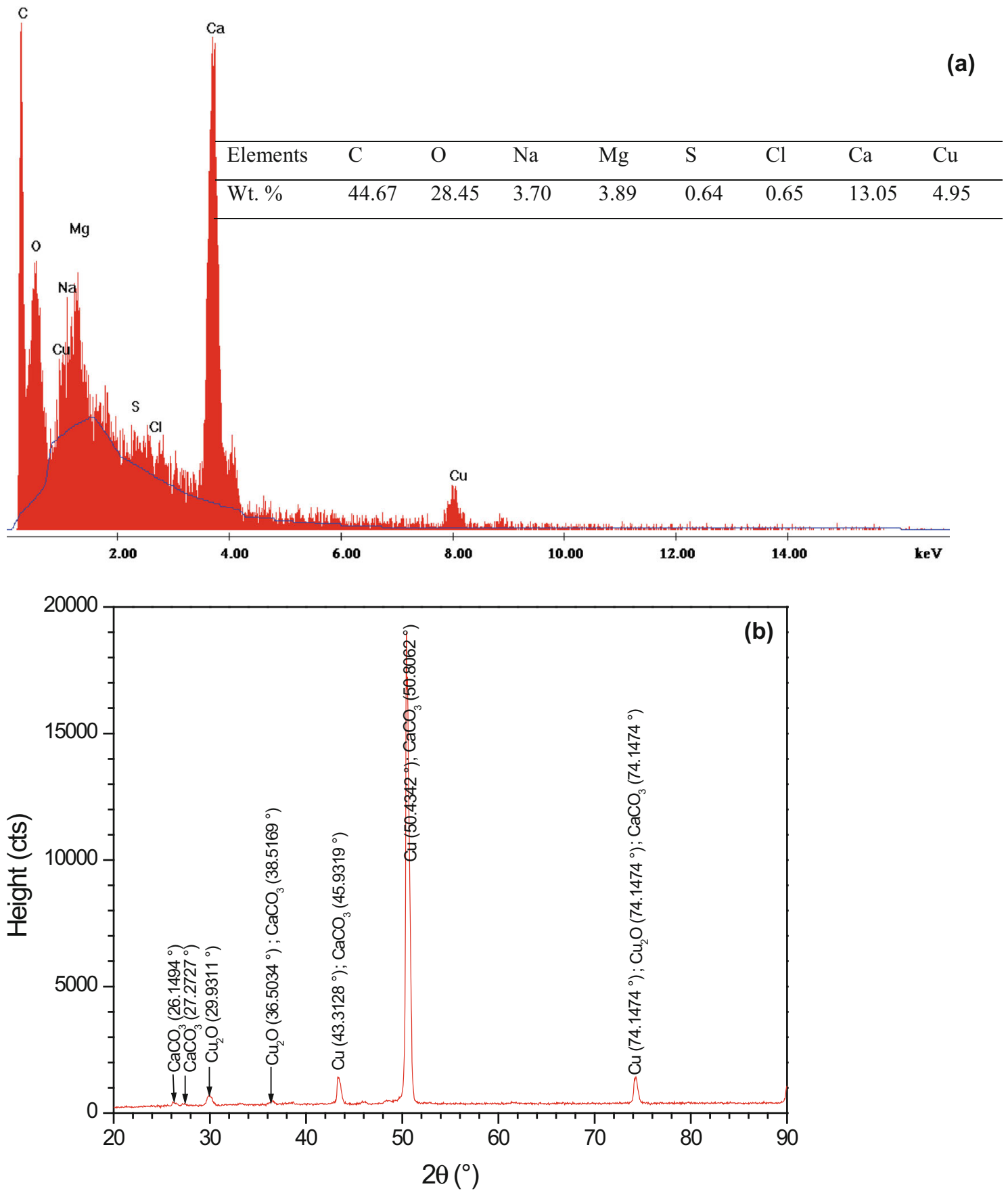

Fig. 2 a EDAX, b XRD spectra for copper surface after $24 \mathrm{~h}$ of immersion in make-up water solution at $323 \mathrm{~K}$

formulation was used (Elhousni et al. 2016). For this, we have studied the inhibition of corrosion, scale-forming, and microorganism development of copper in the Moroccan cooling water system by sodium gluconate (SG), cetyltrimethyl ammonium bromide (CTAB), and their mixture using electrochemical measurements coupled with scanning electron microscopy (SEM). It was found that the SG acts as a cathodic-type inhibitor and its inhibition is about $95 \%$ at $10^{-3} \mathrm{M}$ and the CTAB acts as a mixed-type inhibitor and its best inhibition is at $15 \mathrm{ppm}$. In addition, the synergistic effect of SG/CTAB study indicated that CTAB decreases the performance of SG from 95 to $88 \%$ and increases with immersion time.

In addition, Fig. $4 \mathrm{~b}$ represents the Nyquist plot of copper in make-up water at the open circuit potential. It is shown that the obtained plot is an imperfect semicircle in the low-frequency region preceded by a straight line at high-frequency range. Generally, the high-frequency loop 


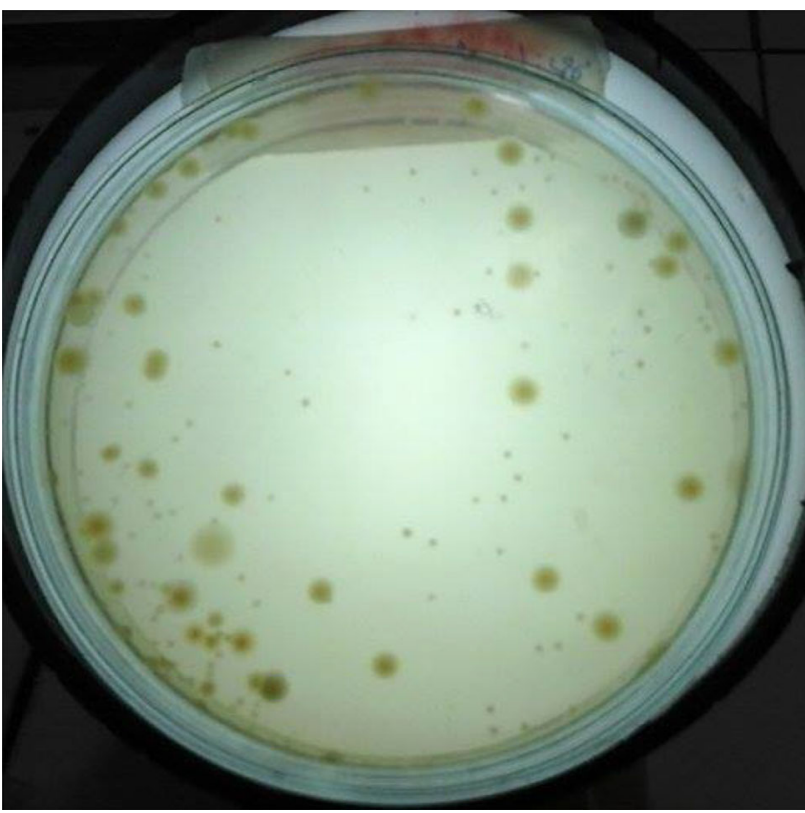

Fig. 3 Results of the agar diffusion method on the middle MullerHilton for make-up water

was attributed to the adsorbed spices $\left(R_{\mathrm{ad}}\right.$ and $\left.C_{\mathrm{ad}}\right)$ and the second loop at the low frequency was attributed to the resistance transfer charge $\left(R_{\mathrm{ct}}\right)$ and double layer capacitance $\left(C_{\mathrm{dl}}\right)$. The corresponding equivalent circuit fitted the impedance data is shown in the insert of Fig. $4 \mathrm{~b}$. Here, $R_{\mathrm{s}}$ is the solution resistance, $R_{\mathrm{ad}}$ is the resistance of the adsorbed species copper surface, and $R_{\mathrm{ct}}$ represents the charge transfer resistance. $Q_{\mathrm{ad}}$ and $Q_{\mathrm{dl}}$ are constant phaseangle elements (CPE), representing an adsorbed species capacitance $\left(C_{\mathrm{ad}}\right)$ and double-layer capacitance $\left(C_{\mathrm{dl}}\right)$, respectively.

However, the calculation of the current density $i_{\text {corr }}$ from polarization resistance determined from the impedance diagram $\left(R_{\mathrm{p}}=8.07 \mathrm{k} \Omega \quad \mathrm{cm}^{2}\right)$ gives $6.63 \mu \mathrm{A} \mathrm{cm} \mathrm{cm}^{-2}$. Therefore, the estimated value from the polarization curves is $8.44 \mu \mathrm{A} \mathrm{cm}^{-2}$. This difference was attributed to that the polarization resistance estimated from potentiodynamic polarization curves encompasses the charge transfer resistance and the resistance of the dissolved oxygen diffusion to the copper surface or the transportation of soluble cuprous chloride complexes from the copper surface to the bulk solution.

\section{Operational parameter effect on scale formation}

$\mathrm{pH}$ is a very important parameter that controls the scale formation and the corrosion character. In fact, water at $\mathrm{pH}$ below 7 can promote corrosion of metal pipes while at a high $\mathrm{pH}$ can lead to scale deposits in cooling water circuits. In our case, the $\mathrm{pH}$ value is about 8.2 conducted to the
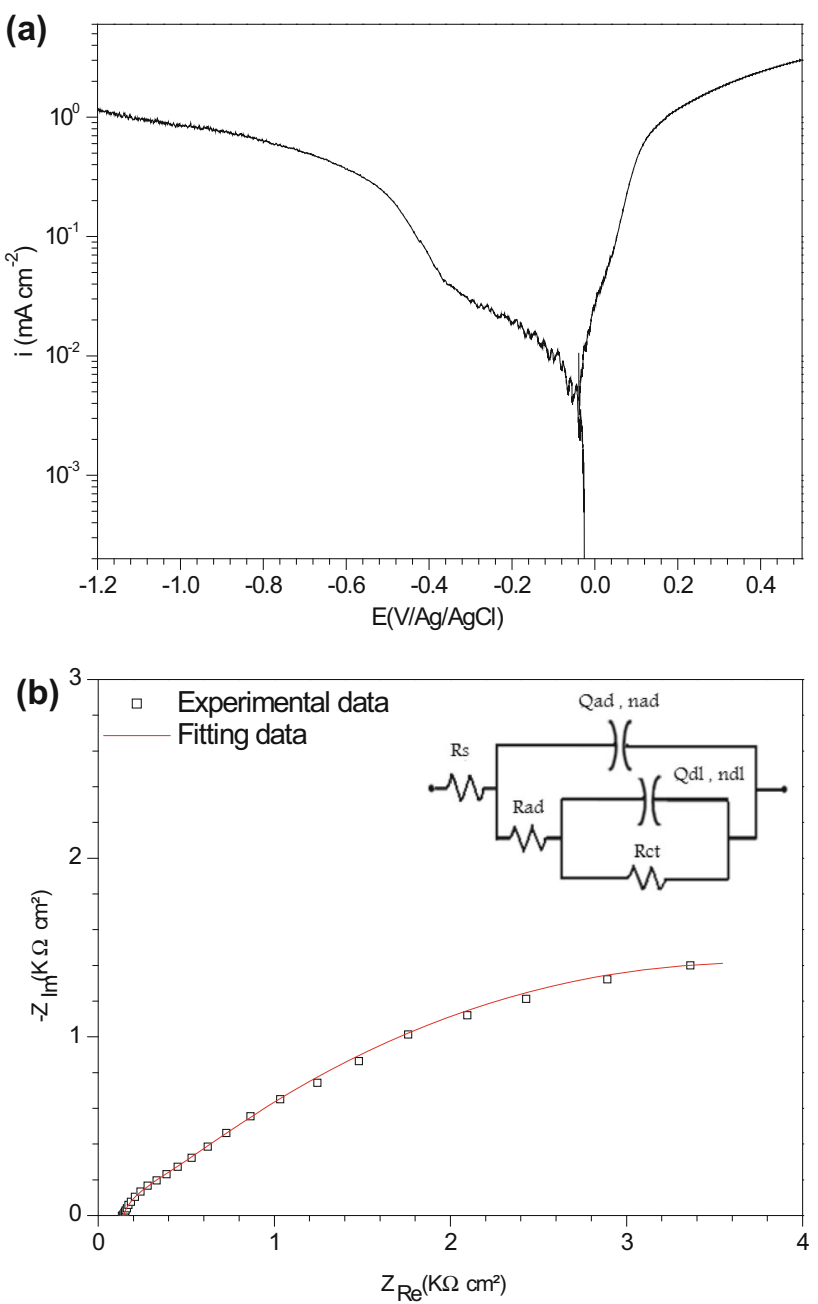

Fig. 4 a Potentiodynamic polarization curve and b Nyquist plot combined with equivalent circuit used to fit the EIS data of copper in make-up water solution at $T=305 \mathrm{~K}$

scale formation such as mentioned above. For this, Fig. 5a presents the effect of the $\mathrm{pH}$ solution, by addition of $\mathrm{NaOH}$ or $\mathrm{H}_{2} \mathrm{SO}_{4}$, on the scale formation by the determination of the free $\mathrm{Ca}^{2+}$ concentrations using ion chromatography. It is noted that at a pH level between 6.5 and 8.2, the free $\mathrm{Ca}^{2+}$ concentration remains almost constant. Thus, an increase of $\mathrm{pH}$ beyond 8.2 caused a remarkable decrease in the free $\mathrm{Ca}^{2+}$ concentration, indicating that the scaling process was intensified. In fact, the $\mathrm{pH}$ of the natural waters was generally between 6 and 8 . At a pH range from 7 to 8 , less than $2 \%$ of carbonates are in the form of $\mathrm{CO}_{3}{ }^{2-}$ and $\mathrm{H}_{2} \mathrm{CO}_{3}{ }^{-}$of the majority $\mathrm{HCO}_{3}{ }^{-}$(Mulford 1964). Lee and Ambrose observed that at a $\mathrm{pH}$ of 7.9, the formed scale was finer than that formed at $\mathrm{pH} \mathrm{8.3,} \mathrm{when} \mathrm{they} \mathrm{studied} \mathrm{the}$ effect of applied potential, fluid velocity, $\mathrm{pH}$, and temperature on the calcareous deposit formation under impressed current cathodic protection (Lee and Ambrose 1986). They also found that the scale deposit depends 

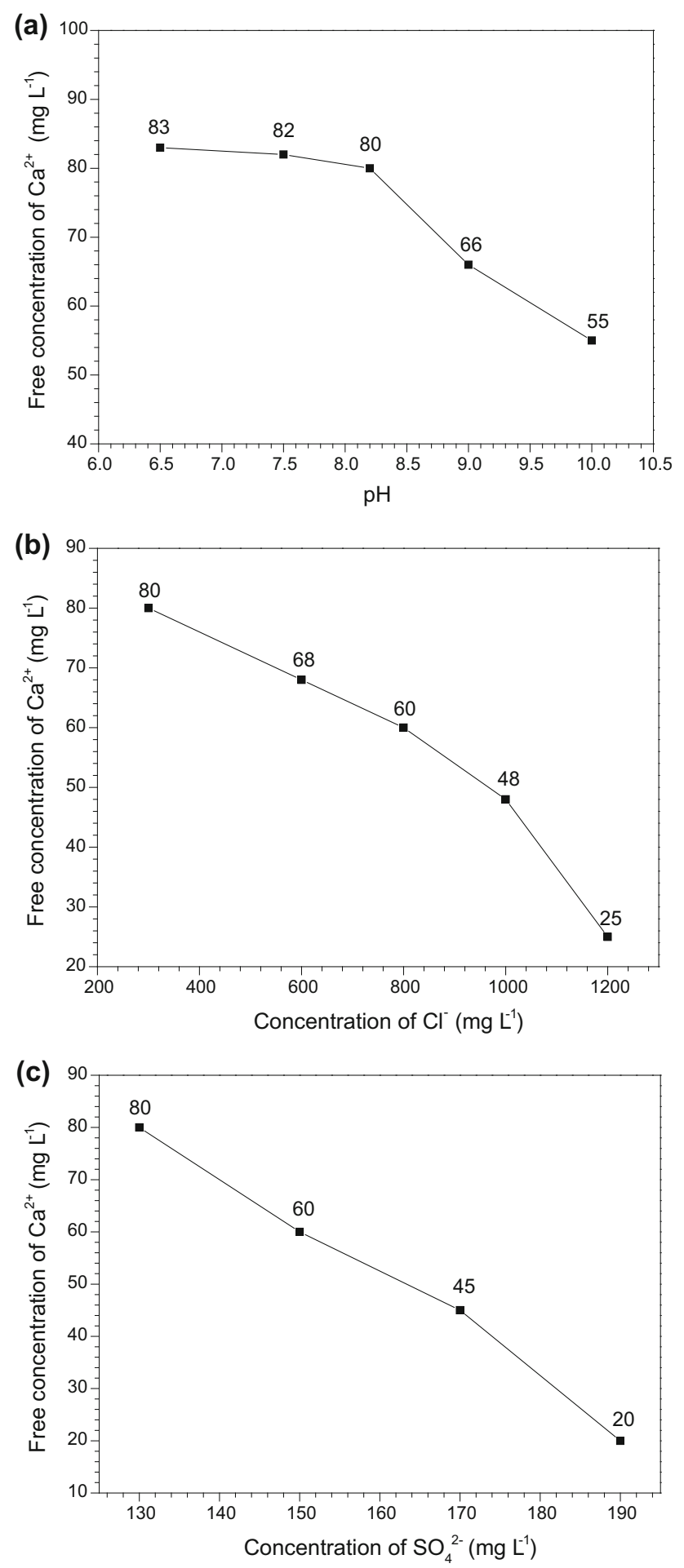

Fig. 5 Effect of a pH solution, $\mathbf{b ~ C l}{ }^{-}$, and $\mathbf{c} \mathrm{SO}_{4}{ }^{2-}$ ions concentration on the free $\mathrm{Ca}^{2+}$ concentration in the solution

primarily on interface $\mathrm{pH}$, which was much higher than the electrolyte. Thus, the variation of bulk $\mathrm{pH}$ had little influence on the cathodic reaction rate, which was measured in terms of current, though $\left[\mathrm{HO}^{-}\right]$is in the reaction path for both oxygen reduction and hydrogen evolution reactions:
$\mathrm{O}_{2}+2 \mathrm{H}_{2} \mathrm{O}+4 e^{-} \leftrightarrow 4 \mathrm{HO}^{-}$

$2 \mathrm{H}_{2} \mathrm{O}+2 e^{-} \leftrightarrow \mathrm{H}_{2}+2 \mathrm{HO}^{-}$

The fact that the cathodic current is mainly comprised of hydrogen evolution and oxygen reduction currents allows us to interpret the measured $\mathrm{pH}$ effect as the sum of the two corresponding parts. Therefore, the oxygen reduction reaction is diffusion-controlled at the potentials of their study. Therefore, variation in $\mathrm{pH}$ should not have any influence on oxygen reduction current, though $\left[\mathrm{HO}^{-}\right]$is in the reaction path of the oxygen-reduction reaction ( $\mathrm{Lu}$ and Fabuss 1968). In contrast, hydrogen evolution is kinetically controlled. Therefore, a decrease in $\mathrm{pH}$ from 8.3 to 7.9 is expected to yield a slight increase in the hydrogen evolution current where its amount can be calculated from the relationship between current and over-potential. Indeed, in our case, the formed scale layer was thick $(\mathrm{pH} \mathrm{8.2)}$, in agreement with the obtained results by SEM.

However, as indicated in Table 1, the amount of chloride and sulfate ions were 300 and $130 \mathrm{mg} \mathrm{l}^{-1}$, respectively. The presence of these ions with a high concentration leads to corrosion and bio-corrosion problems. So, Huttunen-Saarivirta indicated that in the presence of microorganisms (e.g., sulfate-reducing bacteria), the development of $\mathrm{Cu}_{2} \mathrm{~S}$ is the primary surface process on copper specimens, with its corrosion protection properties being regulated by the growth of bio-film. As compared to the two layers of $\mathrm{Cu}_{2} \mathrm{O}$ that grow on the specimen surfaces in the absence of bacteria, $\mathrm{Cu}_{2} \mathrm{~S}$ films were essentially less susceptible for the $\mathrm{Cl}^{-}$attack. They found that under abiotic conditions, the passivity breakdown by $\mathrm{Cl}^{-}$ions resulted in the localized type of attack detected on the surfaces. This finding is the probable reason for an essentially higher corrosion rate than in the biotic system (Huttunen-Saarivirta et al. 2016). For this, we have studied the influence of chloride and sulfate ions on the scale formation, such as presented in Fig. 5b, c. It is noted that the free $\mathrm{Ca}^{2+}$ concentration decreases linearly with increasing of $\mathrm{Cl}^{-}$and $\mathrm{SO}_{4}{ }^{2-}$ ions. This finding can be explained by the formation of $\mathrm{CaCl}_{2}$ and $\mathrm{CaSO}_{4}$ on the metallic surface.

However, an electrochemical study of the scale process has shown that at different applied potentials, an increase in the chloride ions concentration resulted in the formation of a porous deposit. Indeed, according to the small size of the chloride ions, they can penetrate between the joints of the formed deposit (Ben Amor 1999).

In the other, the presence of sulfate ions caused the formation of a porous scale layer where its porosity is larger than that formed in the case of chloride ions (Ben Amor 1999). 

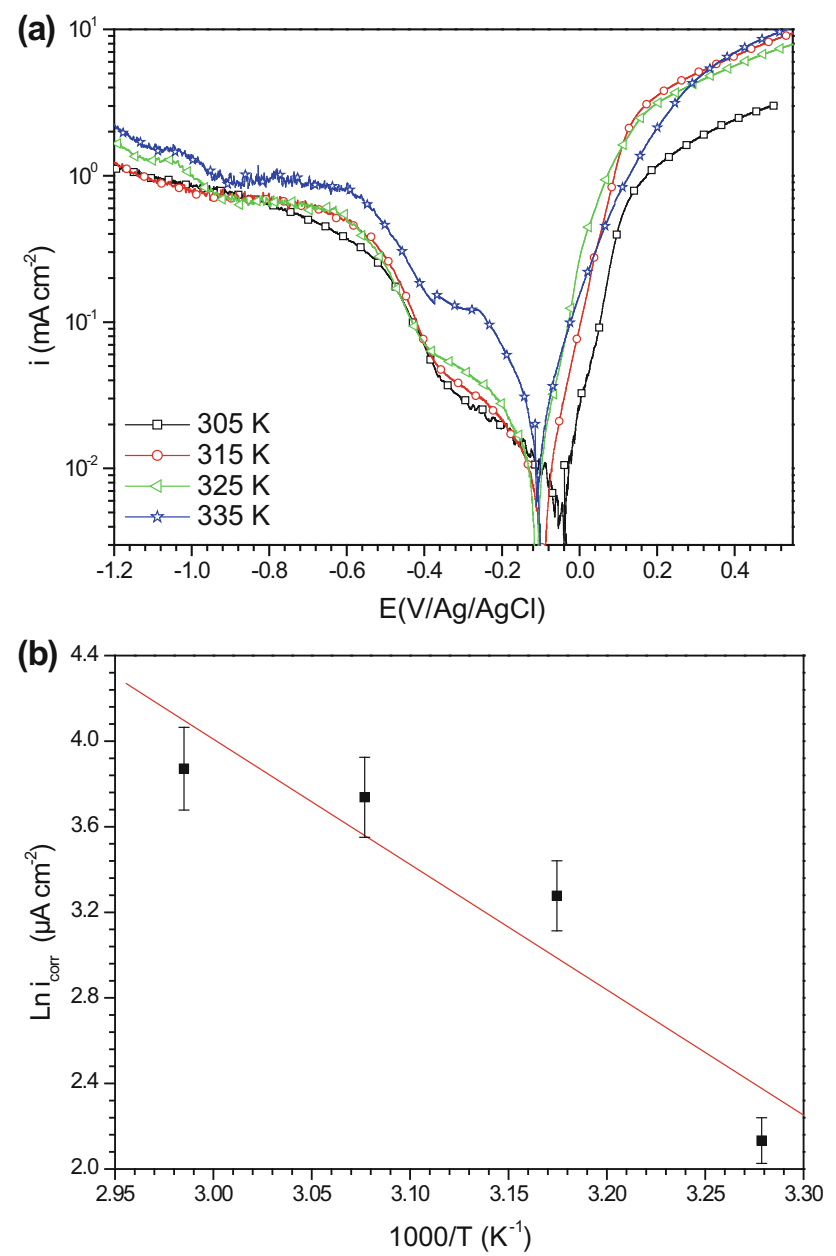

Fig. 6 a Potentiodynamic polarization curves of copper in make-up water at different temperature, and $\mathbf{b} \mathrm{Ln} i_{\text {corr }}$ vs. 1/T plot used to calculate the Arrhenius slope

\section{Operating parameters effect on corrosion}

\section{Effect of temperature solution}

The corrosive medium temperature is an essential parameter in the operation of cooling water systems. It is considered one of the factors that may affect the substrate behavior in an aggressive environment. For this, the potentiodynamic polarization curves for copper in make-up water were carried out at different temperatures range from 305 to $335 \mathrm{~K}$. The choice of this temperature range was justified by the fact that iron, copper, and their alloys used in the cooling water systems where their temperature could reach $335 \mathrm{~K}$ (Amar et al. 2006). Figure 6a presents the obtained results. It is noted that the anodic and cathodic branches change in form with temperature, indicating a change in the behavior of copper in make-up water. This effect was attributed to the increase of the diffused oxygen quantity in the solution with temperature (Stern and Geary 1957). Table 5 showed that the current density increases with temperature, indicating an increase in the copper corrosion rate.

However, the corrosion rate versus temperature can be expressed by the Arrhenius equation:

$i_{\text {corr }}=K \exp \left(-\frac{E_{a}}{R T}\right)$,

where $i_{\text {corr }}$ is the corrosion current density $\left(\mathrm{A} \mathrm{cm}^{-2}\right), \mathrm{K}$ is the frequency factor, $E_{\mathrm{a}}$ is the activation energy of the copper corrosion reaction, $R$ is the universal gas constant $\left(8.314 \mathrm{~J} \mathrm{~mol}^{-1} \mathrm{~K}^{-1}\right)$, and $\mathrm{T}$ is the absolute temperature (K).

The obtained plot $\ln i_{\text {corr }}$ vs. 1/T is given in Fig. $6 \mathrm{~b}$. The obtained experimental curve corresponds approximately to a straight line and the $E_{a}$ value can be obtained from its slope. The obtained value of $E_{\mathrm{a}}$ is $48.72 \pm 6.02 \mathrm{~kJ} \mathrm{~mol}^{-1}$ (Table 5), which is greater than that obtained for copper in $0.5 \mathrm{M} \mathrm{NaCl}\left(17.9 \mathrm{~kJ} \mathrm{~mol}^{-1}\right)$, indicates the corrosion character of the studied water (Rahal et al. 2016).

\section{Effect of $p H$ solution}

Figure 7 shows the Nyquist plots of copper in make-up water solution at different $\mathrm{pH}$ values. It is shown that the obtained Nyquist plots were composed of two loops, the first at a high frequency and the second at a low frequency range. Generally, the first was attributed to the adsorbed species at the metallic surface and the second was attributed to the charge transfer resistance $\left(R_{\mathrm{ct}}\right)$ and double-layer capacitance $\left(C_{\mathrm{dl}}\right)$. The proposed equivalent circuit is shown in the insert of Fig. 7 and the obtained electrochemical parameters are listed in Table 6. It is noted that both values $R_{\mathrm{ct}}$ and $R_{\mathrm{ad}}$ increase with $\mathrm{pH}$. This effect can be explained by the formation of a pseudo protective film by the adsorption of corrosion $\left(\mathrm{CuO}_{2}\right)$ and scale $\left(\mathrm{CaCO}_{3}\right)$ products such as mentioned above and confirmed by XRD spectra.
Table 5 Electrochemical parameters of copper in makeup water solution at different temperatures

\begin{tabular}{lcclcc}
\hline$T(\mathrm{~K})$ & $E_{\text {corr }}(\mathrm{mV} / \mathrm{Ag} / \mathrm{AgCl})$ & $I_{\text {corr }}\left(\mu \mathrm{A} \mathrm{cm}^{-2}\right)$ & $\beta_{\mathrm{c}}\left(\mathrm{mV} \mathrm{dec}^{-1}\right)$ & $\beta_{\mathrm{a}}\left(\mathrm{mV} \mathrm{dec}^{-1}\right)$ & $E_{\mathrm{a}}\left(\mathrm{kJ} \mathrm{mol}^{-1}\right)$ \\
\hline 305 & -24.0 & 8.44 & -190 & 100 & $48.72 \pm 6.02$ \\
315 & -88.6 & 26.50 & -177 & 82 & \\
325 & -108.0 & 42.00 & -192 & 79 & \\
335 & -95.0 & 48.00 & -138 & 75 & \\
\hline
\end{tabular}




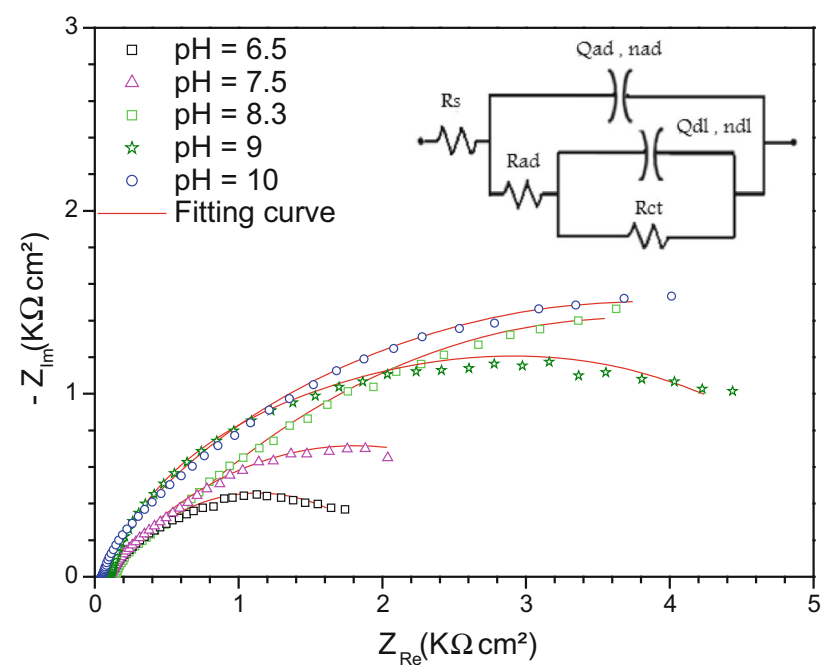

Fig. 7 Nyquist plots for copper in make-up water solution at different $\mathrm{pH}$ solution, combined with equivalent circuit used to fit the EIS data

\section{Immersion time}

Figure 8 shows Nyquist plots for copper in make-up water solution after different immersion times. The obtained diagrams show the presence of two semicircles. The first loop may correspond to the formation of corrosion and scale products on the metallic surface. The second loop was attributed to the charge transfer and double-layer capacitance. The analysis of these plots was performed with the proposed equivalent circuit presented in the insert of Fig. 8. This model was used in our previous works to

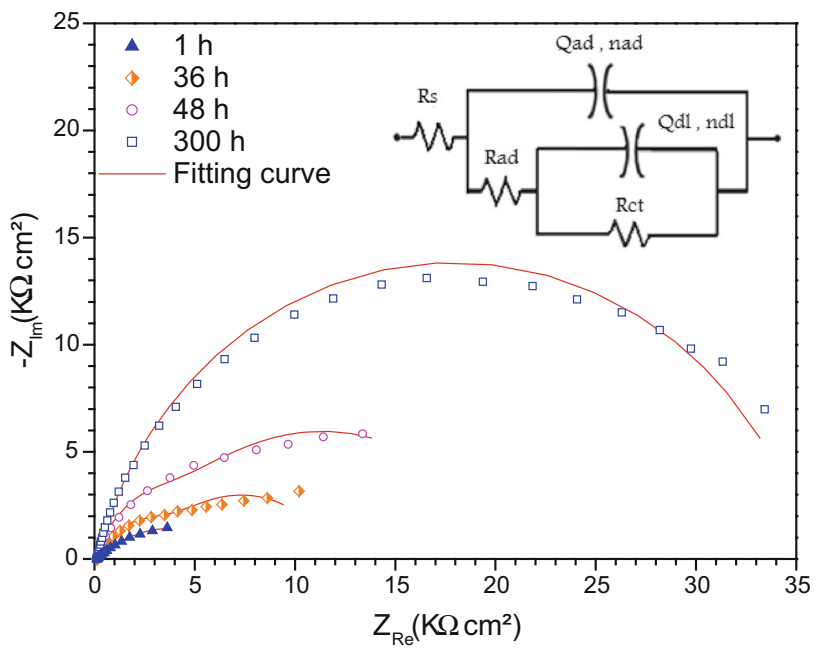

Fig. 8 Nyquist plots for copper in make-up water solution at different immersion times, combined with an equivalent circuit used to fit the EIS data

describe the behavior of copper and brass in cooling water solution, with or without inhibitors (Elhousni et al. 2016; El Bakri et al. 2016; Rochdi et al. 2014). In this model, $R_{\mathrm{s}}$ is the solution resistance, $R_{\mathrm{ct}}$ is the charge transfer resistance, $Q_{\mathrm{dl}}$ corresponds to the capacitance of the double layer, and the $R_{\mathrm{ad}}$ and the element $Q_{\mathrm{ad}}$ correspond to the film formation of corrosion and scale products. Actually, $Q_{\mathrm{dl}}$ and $Q_{\mathrm{ad}}$ represent constant phase elements (CPE) used in the place of capacitors to compensate for deviations from ideal dielectric behavior. These deviations were attributed the inhomogeneous nature of the electrode due to surface roughness, inhibitor adsorption, porous layer
Table 6 Impedance parameters of copper in make-up water solution at different $\mathrm{pH}$, immersion time, and chloride ion concentration

\begin{tabular}{cllllll}
\hline Parameters & $\begin{array}{l}R_{\mathrm{s}} \\
\mathrm{k} \Omega \mathrm{cm}^{2}\end{array}$ & $\begin{array}{l}C_{\mathrm{ad}} \\
\mu \mathrm{F} \mathrm{cm}\end{array}$ & $\begin{array}{l}R_{\mathrm{ad}} \\
\mathrm{k} \Omega \mathrm{cm}^{2}\end{array}$ & $\begin{array}{l}C_{\mathrm{dl}} \\
\mu \mathrm{F} \mathrm{cm} \mathrm{cm}^{-2}\end{array}$ & $\begin{array}{l}R_{\mathrm{ct}} \\
\mathrm{k} \Omega \mathrm{cm}^{2}\end{array}$ & $\begin{array}{l}R_{\mathrm{p}} \\
\mathrm{k} \Omega \mathrm{cm}^{2}\end{array}$ \\
\hline $\mathrm{pH}$ & & & & & \\
6.5 & 0.097 & 77 & 0.6 & 285 & 2 & 1.60 \\
7.5 & 0.104 & 82 & 0.4 & 244 & 3.5 & 2.90 \\
8.3 & 0.123 & 50 & 1 & 140 & 7.2 & 8.07 \\
9 & 0.120 & 48 & 1.2 & 188 & 5.5 & 5.50 \\
10 & 0.114 & 44 & 1.4 & 122 & 7 & 7.30 \\
Time (h) & & & & & \\
1 & 0.123 & 50 & 1 & 140 & 7.2 & 8.07 \\
36 & 0.141 & 106 & 5 & 279 & 16.2 & 21 \\
48 & 0.124 & 68 & 11.5 & 84 & 20.2 & 32 \\
300 & 0.130 & 223 & 1.9 & 13 & 36.4 & 38 \\
{$\left[\mathrm{Cl}{ }^{-}\right](\mathrm{ppm})$} & & & & & & \\
400 & 0.123 & 50 & 1 & 140 & 7 & 8 \\
600 & 0.101 & 44 & 2 & 255 & 6 & 7 \\
800 & 0.080 & 51 & 1 & 284 & 6 & 3 \\
1000 & 0.058 & 60 & 1 & 305 & 2 & 2 \\
1200 & 0.057 & 75 & 1 & 344 & 2 & \\
\hline
\end{tabular}




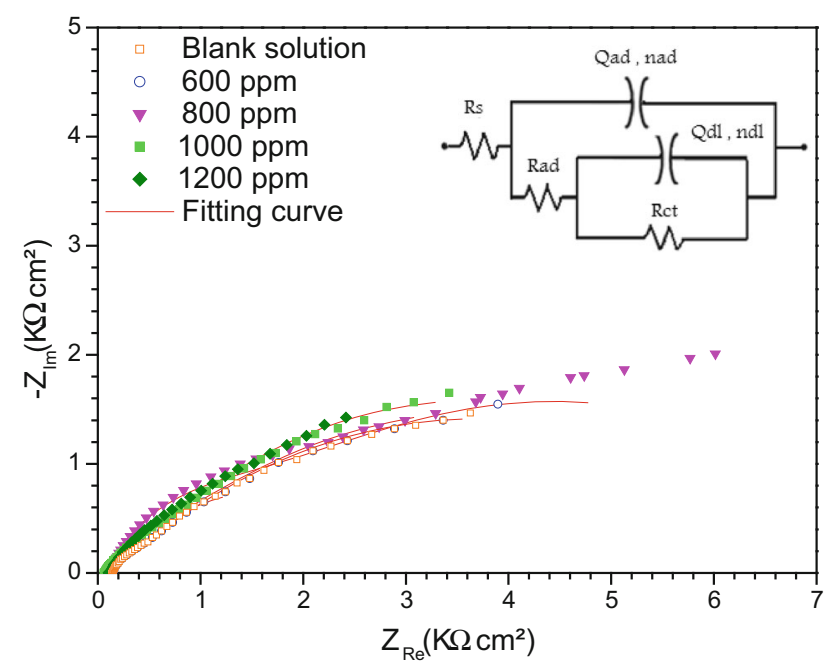

Fig. 9 Nyquist plots for copper in make-up water solution at different chloride ions, combined with equivalent circuit used to fit the EIS data

formation, etc. The obtained electrochemical parameters are listed in Table 6 , where $R_{\mathrm{p}}$ is the total polarization resistance of copper in the solution $\left(R_{\mathrm{p}}\right.$ is the sum of $R_{\mathrm{ad}}$ and $\left.R_{\mathrm{ct}}\right)$. It is noted that $R_{\mathrm{ct}}$ and $R_{\mathrm{ad}}$ increase with immersion time to reach 38 and $11 \mathrm{k} \Omega \mathrm{cm}^{2}$, respectively. These results explained why the curve's nature changes with the times.

\section{Effect of $\mathrm{Cl}^{-}$ions}

Figure 9 shows the Nyquist diagrams obtained from copper in make-up water solution at different concentrations of $\mathrm{Cl}^{-}$ions. The obtained plots were composed of two loops, one at high frequency, which corresponds to the formation of corrosion and scale products on the copper surface. The other loop at low frequency was mainly attributed to the charge transfer and double-layer capacitance. So, the analysis of these diagrams was performed with the proposed equivalent circuit presented in the insert of Fig. 9 and the obtained parameters are listed in Table 6. It is noted that the $R_{\mathrm{ct}}$ decreases with an increase of chloride ions. The best decrease was observed at 1000 and $1200 \mathrm{ppm}$. In addition, generally no change was observed for $R_{\mathrm{ad}}$. However, the decrease of $R_{\mathrm{p}}$ was mainly due to the decrease of $R_{\mathrm{ct}}$ with the rise of chloride ions.

\section{Conclusions}

Electrochemical measurements coupled with SEM/EDAX and X-ray diffraction analyses were used to investigate corrosion and scale process of copper in the Moroccan industrial cooling water system. It is shown that this water contains several elements responsible for corrosion and scale formation, such as $\mathrm{Cl}^{-}, \mathrm{Ca}^{2+}, \mathrm{Mg}^{2+}, \mathrm{HCO}_{3}{ }^{-}$ions. These findings were confirmed by EDAX and XRD analyses. In fact, the EDAX and XRD analyses indicated that the major corrosion and scale products were $\mathrm{CuO}_{2}$ and $\mathrm{CaCO}_{3}$, respectively. In addition, the middle MuellerHinton test for the development of microorganisms indicated the presence and colonization of microbial species in make-up water. Finally, it was found that the scale rate increases with $\mathrm{pH}$, temperatures, and the presence of chloride and sulfide ions. On the other hand, electrochemical measurements indicated that the increase of temperature and chloride ion concentrations cause an increase in the corrosion rate. Additionally, the electrochemical impedance spectroscopy showed that the polarization resistance of the copper increases with $\mathrm{pH}$ and immersion time, which can be explained by the formation of a protective layer composed of corrosion and scale products.

Acknowledgements The authors appreciate the experimental support given by all members of 'Laboratoire d'Ingénierie des Matériaux et d'Environnement : Modélisation et Application, Faculté des Sciences, Université Ibn Tofail'.

\section{Compliance with ethical standards}

Conflict of interest All of the authors have declared no conflicts of interest.

\section{References}

Amar H, Benzakour J, Derja A, Villemin D, Moreau B, Braisaz T (2006) Piperidin-1-yl-phosphonic acid and (4-phosphono-piperazin-1-yl) phosphonic acid: a new class of iron corrosion inhibitors in sodium chloride $3 \%$ media. J Appl Surf Sci 252:6162-6172. doi:10.1016/j.apsusc.2005.07.073

Amor YB (1999) Influence des ions chlorure, sulfate et magnésium sur l'entartrage de l'acier ordinaire: Etude électrochimique et analytique. Sc. de Tunis, Fac

Bech-Nielsen G, Jaskula M, Chorkendorff I, Larsen J (2002) The initial behaviour of freshly etched copper in moderately acid, aerated chloride solutions. Electrochim Acta 47:4279-4290. doi: 10.1016/S0013-4686(02)00415-2

Bojinov M, Betova I, Lilja C (2010) A mechanism of interaction of copper with a deoxygenated neutral aqueous solution. Corros Sci 52:2917-2927. doi:10.1016/j.corsci.2010.05.003

Chantereau J (1980) Corrosion bactérienne. Technique et documentation, pp 151-170

Chen W, Hong S, Li HB, Luo HQ, Li M, Li NB (2012) Protection of copper corrosion in $0.5 \mathrm{M} \mathrm{NaCl}$ solution by modification of 5-mercapto-3-phenyl-1,3,4-thiadiazole-2-thione potassium selfassembled monolayer. Corros Sci 61:53-62. doi:10.1016/j. corsci.2012.04.023

El Bakri M, Touir R, Tazouti A, Dkhireche N, Ebn Touhami M, Rochdi A, Zarrouk A (2016) Corrosion inhibition study of brass in simulated cooling water by triazole derivatives, cetyltrimethylammonium bromide and their mixture. Arab J Sci Eng 41:75-88. doi:10.1007/s13369-014-1532-6 
ELbakri M, Touir R, Ebn Touhami M, Srhiri A, Benmessaoud M (2008) Electrosynthesis of adherent poly(3-amino-1,2,4-triazole) films on brass prepared in nonaqueous solvents. Corros Sci 50:1538-1545

Elhousni L, Galai M, ElKamraoui FZ, Dkhireche N, Ebn Touhami M, Touir R, Chebabe D, Sfaira M, Zarrouk A (2016) Study of sodium gluconate and cetyltrimethyl ammonium bromide as inhibitor for copper in Moroccan industrial cooling water systems. J Mater Environ Sci 7:2513-2525

Enning D, Venzlaff H, Garrelfs J, Dinh HT, Meyer V, Mayrhofer K, Hassel AW, Stratmann M, Widdel M (2012) Marine sulfatereducing bacteria cause serious corrosion of iron under electroconductive biogenic mineral crustemi. Environ Microb 14:1772-1787

Eriksen TE, Ndalamba P, Grenthe I (1989) On the corrosion of copper in pure water. Corros Sci 29:1241-1250. doi:10.1016/0010938X(89)90071-1

Hamilton WA (1985) Sulphate-reducing bacteria and anaerobic corrosion. Annu Rev Microbiol 39:195-217

Harris A, Marshall A (1981) The evaluation of scale control additives. Conference on Progress in the prevention of fouling in industrial plant. University Nottingham

Herrmann S, Kostrzewa M, Wierschem A, Streb C (2014) Polyoxometalate ionic liquids as self-repairing acid-resistant corrosion protection. Angew Chem Int Ed 53:13596-13599. doi:10.1002/ anie. 201408171

Huttunen-Saarivirta E, Rajala P, Carpén L (2016) Corrosion behaviour of copper under biotic and abiotic conditions in anoxic ground water: electrochemical study. Electrochim Acta 203:350-365. doi:10.1016/j.electacta.2016.01.098

Kartsonakis IA, Koumoulos EP, Karantonis A, Charitidis CA, Dessypris S, Monos A (2015) Study of corrosion of copper in industrial cooling systems. Inter $\mathrm{J}$ Struct Integr 6:617-635. doi:10.1108/IJSI-10-2013-0039

Kear G, Barker BD, Walsh FC (2004) Electrochemical corrosion of unalloyed copper in chloride media - a critical review. Corros Sci 46:109-135. doi:10.1016/S0010-938X(02)00257-3

Ketrane R, Saidani B, Gil O, Leleyter L, Baraud F (2009) Efficiency of five scale inhibitors on calcium carbonate precipitation from hard water: effect of temperature and concentration. Desalination 249:1397-1404. doi:10.1016/j.desal.2009.06.013

Kosec T, Qin Z, Chen J, Legat A, Shoesmith DW (2015) Copper corrosion in bentonite/saline groundwater solution: effects of solution and bentonite chemistry. Corros Sci 90:248-258. doi:10. 1016/j.corsci.2014.10.017

Langelier Wilfred F (1936) The analytical control of anti-corrosion water treatment. J Am Water Works Assoc 28:1500-1521

Lee RU, Ambrose JR (1986) Corrosion/86 paper no 292. Huston, Texas

Lee W, Lewandowski Z, Nielsen PH, Hamilton WA (1995) Role of sulfate-reducing bacteria in corrosion of mild-steel-a review. Biofouling 8:165-194

Lu CH, Fabuss BM (1968) Calcium sulfate scaling in saline water distillation. Ind Eng Chem Proc Des Dev 7:206-212. doi:10. 1021/i260026a009

Merkel TH, Pehkonen SO (2006) General corrosion of copper in domestic drinking water installations: scientific background and mechanistic understanding. Corrosion Eng Sci Tech 41:21-37. doi:10.1179/174327806X94009

Mulford SF (1964) Scale control in sea water evaporators, OSW R \& D progress rept, No 133, US Department of Interior

Puchorius PR, Brooke JM (1988) Effectively evaluating cooling water programme, (paper No. 17) presented at the NACEcorrosion Conference, St. Louis, USA

Qiang Y, Zhang S, Xu S, Li W (2016) Experimental and theoretical studies on the corrosion inhibition of copper by two indazole derivatives in $3.0 \% \mathrm{NaCl}$ solution. J Coll Inter Sci 472:52-59. doi:10.1016/j.jcis.2016.03.023

Rahal C, Masmoudi M, Abdelhedi R, Sabot R, Jeannin M, Bouaziz M, Refait P (2016) Olive leaf extract as natural corrosion inhibitor for pure copper in $0.5 \mathrm{M} \mathrm{NaCl}$ solution: a study by voltammetry around OCP. J Electroanal Chem 769:53-61. doi:10.1016/j.jelechem.2016.03.010

Rochdi A, Kassou O, Dkhireche N, Touir R, El Bakri M, Ebn Touhami M, Sfaira M, Mernari B, Hammouti B (2014) Inhibitive properties of 2,5-bis(n-methylphenyl)-1,3,4-oxadiazole and biocide on corrosion, biocorrosion and scaling controls of brass in simulated cooling water. Corros Sci 80:442-452. doi:10.1016/j. corsci.2013.11.067

Ryznar JW (1944) A new index for determining amount of calcium carbonate scale formed by water. J Am Water Works Assoc 36:472-486

Sherif EM, Park S-M (2005) Inhibition of copper corrosion in 3.0\% $\mathrm{NaCl}$ solution by $\mathrm{N}$-Phenyl-1,4-phenylenediamine. J Electrochem Soc 152:B428-B433. doi:10.1149/1.2018254

Soror TY (2009) Scale and corrosion prevention in cooling water systems part I: calcium carbonate. Open Corros J 2:45-50

Srisuwan N, Ochoa N, Pébère N, Tribollet B (2008) Variation of carbon steel corrosion rate with flow conditions in the presence of an inhibitive formulation. Corros Sci 50:1245-1250

Stern M, Geary AL (1957) Electrochemical polarization I. A theoretical analysis of the shape of polarization curves. J Electrochem Soc 104:56-63. doi:10.1149/1.2428496

Touir R, Dkhireche N, Ebn Touhami M, Sfaira M, Senhaji O, Robin JJ, Boutevin B, Cherkaoui M (2010) Study of phosphonate addition and hydrodynamic conditions on ordinary steel corrosion inhibition in simulated cooling water. Mater Chem Phys 122:1-9

Touir R, Dkhireche N, Ebn Touhami M, El Bakri M, Rochdi A, Belakhmima RA (2014) Study of the mechanism action of sodium gluconate used for the protection of scale and corrosion in cooling water system. J Saudi Chem Soc 18:873-881. doi:10. 1016/j.jscs.2011.10.020

Trachli B, Keddam M, Takenouti H, Srhiri A (2002) Protective effect of electropolymerized 3-amino 1,2,4-triazole towards corrosion of copper in $0.5 \mathrm{M} \mathrm{NaCl}$. Corros Sci 44:997-1008. doi:10.1016/ S0010-938X(01)00124-X

Zhao J, Xua D, Babar Shahzad M, Qiang K, Sun Y, Sun Z, Zhang S, Ren L, Yang Ch, Yang K (2016) Effect of surface passivation on corrosion resistance and antibacterial properties of $\mathrm{Cu}$-bearing 316L stainless steel. Appl Surf Sci 386:371-380. doi:10.1016/j. apsusc.2016.06.036 